\title{
Temporal variations in flow velocity at Finsterwalderbreen, a Svalbard surge-type glacier
}

\author{
Anne-Marie NUTTALL, ${ }^{1}$ Richard HODGKINS ${ }^{2}$ \\ ${ }^{1}$ School of Biological and Earth Sciences, Liverpool John Moores University, Byrom Street, Liverpool L3 3AF, UK \\ E-mail: A.Nuttall@livjm.ac.uk \\ ${ }^{2}$ Department of Geography, Royal Holloway, University of London, Egham, Surrey TW20 OEX, UK
}

\begin{abstract}
Inter- and intra-annual velocity variations are well known on alpine glaciers, but their importance for Arctic glaciers has only been recognized more recently. This paper presents flow velocity data from Finsterwalderbreen, a $35 \mathrm{~km}^{2}$ polythermal surge-type glacier in southern Svalbard that is presently $\sim \mathbf{1 0 0}$ years into its quiescent phase. Field measurements of glacier surface velocities are available from 1950-52 and 1994-97, and mean velocities for the last decade are estimated for the lower glacier using cables drilled to the glacier bed. These velocities show substantial seasonal variations indicating that basal sliding is an important component of surface velocities and interannual fluctuations of up to $75 \%$, possibly indicating variations in subglacial water storage. Several lines of evidence indicate that this glacier has an extensive subglacial hydrological system, generally considered to be a prerequisite for surge-type glaciers, which is at least partly pressurized. Information on surface morphology from 1898 onwards shows that the glacier has experienced continuous retreat since the last surge in about 1910, and has now retreated $\sim 1.5 \mathrm{~km}$ further back than its previous pre-surge position in 1898. Tracking of moraine loops on terrestrial and aerial photographs acquired over a 100 year period indicates that the surge period of Finsterwalderbreen may be lengthening in response to climate changes.
\end{abstract}

\section{INTRODUCTION}

Many glaciological studies in the $61000 \mathrm{~km}^{2}$ Svalbard archipelago $\left(76-81^{\circ} \mathrm{N}, 11-31^{\circ} \mathrm{E}\right)$ have focused on surge-type glaciers, partly because they are so prevalent there. As the surge cycle is atypically long in this sparsely populated region (Dowdeswell and others, 1991), only five glaciers have been observed to surge more than once. These five glaciers have surge periods ranging from $\sim 40$ to 140 years (Hagen and others, 1993), with the length of the quiescent phase showing a positive correlation with glacier area (Nuttall, 2000).

Using different approaches, the proportion of surge-type glaciers in Svalbard has been estimated by Lefauconnier and Hagen (1991) to be $90 \%$, by Hamilton and Dowdeswell (1996) to be $36 \%$ and by Jiskoot and others (1998) to be $13 \%$. It has been suggested that this proportion may decrease with time as some surge-type glaciers fail to accumulate the mass necessary to trigger a subsequent surge because of post-Little Ice Age climatic warming (Dowdeswell and others, 1995). One such glacier, Scott Turnerbreen, has changed from a polythermal regime to an entirely coldbased regime after a surge in the 1930s led to a substantial thinning, and is thus no longer capable of surging (Hodgkins and others, 1999). Recent work in Alaska, USA (Eisen and others, 2001) suggests that a cumulative mass-balance threshold must be reached before a quiescent phase ends and the next active phase begins, rather than a fixed length of time. This implies that a changing climate can affect the length of the quiescent phase, even if the glacier retains the thermal regime necessary for surging.

This paper presents an unusually comprehensive and long-term dataset from a Svalbard surge-type glacier, Finsterwalderbreen $\left(77^{\circ} 29^{\prime} \mathrm{N}, 15^{\circ} 19^{\prime} \mathrm{E}\right)$, comprising velocity, hydrology and morphological data. Implications for the past and future surge behaviour of the glacier are discussed.

\section{STUDY SITE AND SURGE HISTORY}

Finsterwalderbreen is a valley glacier located in the Van Keulenfjord area of southwest Spitsbergen, in the Svalbard archipelago (Nuttall and others, 1997; Fig. 1). At present, it is $\sim 35 \mathrm{~km}^{2}$ in area and $11 \mathrm{~km}$ long. Mean annual air temperatures in this part of Svalbard are typically $-6^{\circ} \mathrm{C}$, while precipitation rates at sea level are $\sim 400 \mathrm{~mm} \mathrm{a}^{-1}$ (Hagen and others, 1993). Multi-frequency radar data and borehole temperature measurements have shown the glacier to be polythermal, with the majority of the bed at the pressure-melting point except near the snout where the ice thins (Ødegård and others, 1997).

Terrestrial photographs from 1898 (Hamberg, 1905) show the glacier terminus to be some distance back from the terminal moraine complex. However, photographs of the glacier front taken in 1918 and 1920 show a thicker glacier terminus right up against these moraines with near-vertical ice cliffs in places, indicating that a surge had taken place between 1898 and 1918 (Liestøl, 1969). There are no crevasses visible in the first available photographs of the upper basin taken in 1920. Based on crevasse healing rates observed at other Svalbard surge-type glaciers (Dowdeswell and others, 1991), it is inferred that the glacier surged at least 5-10 years before this date, i.e. 1910-15, hence the glacier is inferred to have been in the late quiescent phase in 1898 . Aerial photographs taken at intervals throughout the 20th century show a continuous retreat of the glacier terminus since at least 1920 (Fig. 2). The 2003 glacier terminus is located $\sim 2.5 \mathrm{~km}$ up-glacier from the terminal moraines, which is $\sim 1.5 \mathrm{~km}$ further back than the 1898 presurge terminus (Fig. 2). This continued retreat accompanied by a thinning of the lower glacier (Nuttall and others, 1997) is consistent with quiescent-phase behaviour of the receiving area of a surge-type glacier. The climatic warming observed 


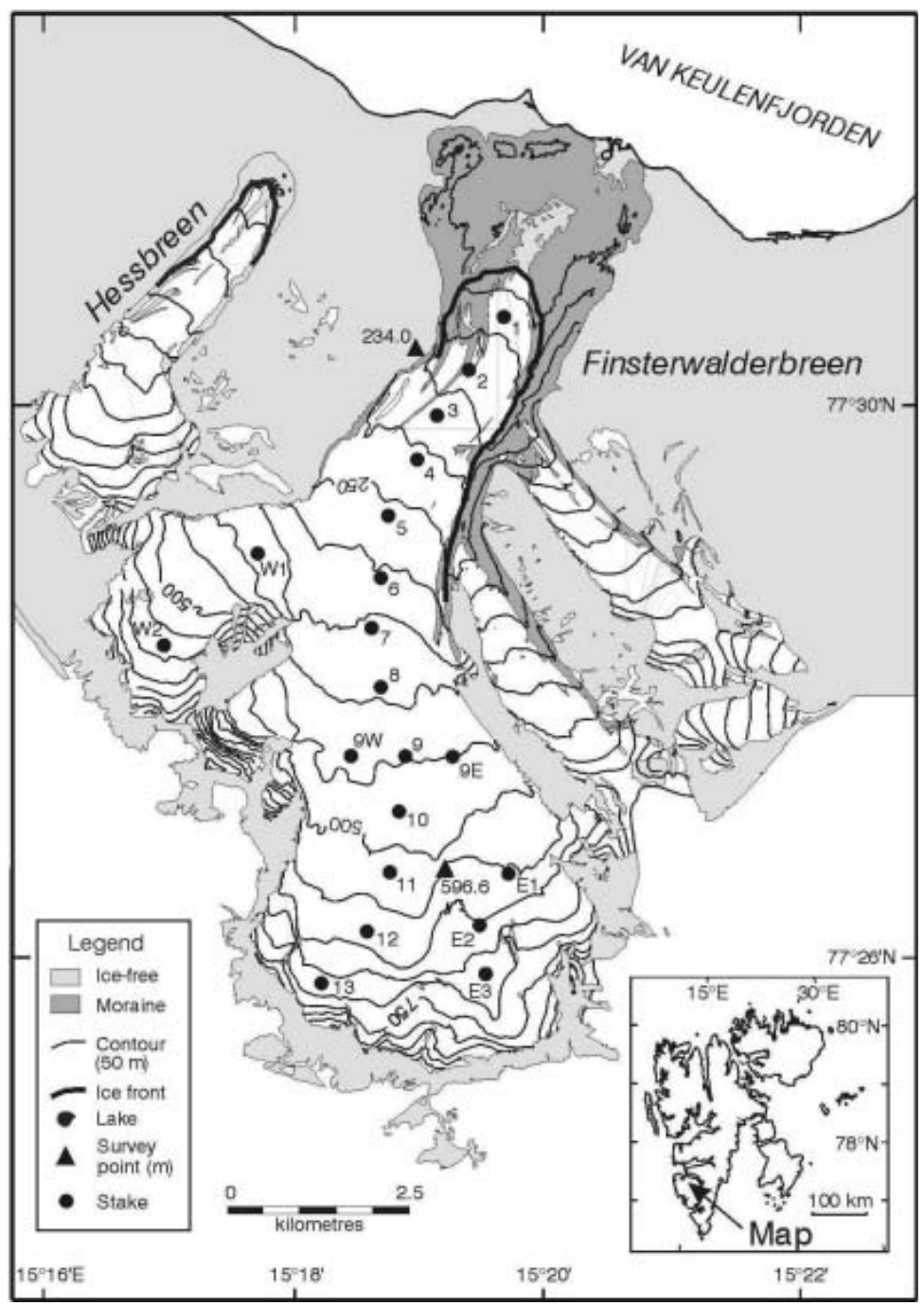

Fig. 1. Map of Finsterwalderbreen showing location of stakes (circles) and survey stations (triangles). Contours from the 1990 digital elevation model are shown at $50 \mathrm{~m}$ intervals. Inset shows the location of the glacier map within Svalbard.

in Svalbard since the end of the Little Ice Age (Dowdeswell and others, 1995) is likely to be responsible for the glacier's retreat far beyond the previous pre-surge position.

Lichenometric dating of the terminal moraine complex by Hart and Watts (1997) gives tentative dates of 1800, 1696 and 1564 for ridges formed by previous advances, although errors are likely to be large on these estimates. These dates would imply an average surge period of $\sim 115$ years, giving a tentative date for the next surge of $\sim 2025-30$.

The $\sim 1910$ surge produced loops in the medial moraines, which are now melting out at the glacier terminus (Fig. 2). Comparison of the lithology of these moraines with the lithology of the basin headwall and nunataks indicates that the surge was initiated in the higher, eastern part of the accumulation basin (Fig. 1). Tracking of the moraine loops through the time series of aerial photographs reveals that the loops seen near the snout in the 1936 photograph (Fig. 3) are not the same set visible in the 1995 aerial photographs (Fig. 2). The latter set have developed from the displaced flowlines visible 1-2 km further up-glacier in 1936 (Fig. 3). This indicates that two surges occurred during the residence time of the ice seen in the 1936 photograph, whereas only one set of looped moraines is currently present, and these will soon have been removed by ablation. This may indicate a lengthening of the quiescent phase, although it should be noted that the glacier is also considerably shorter now than it was in 1936 (Fig. 2), so the residence time of the ice may also be shorter.

\section{GLACIER VELOCITIES}

Seasonal velocity variations have previously been reported from Arctic glaciers, both surge-type and normal (e.g. Erikbreen, Svalbard (Etzelmüller and others, 1993); Variegated Glacier, Alaska (Raymond and Harrison, 1988); John Evans Glacier, Canada (Copland and others, 2003)), although datasets are sparse compared to Alpine studies. Detailed investigations at Haut Glacier d'Arolla, Swiss Alps, showed a maximum in observed velocities in spring (June), as meltwater production increased and led to high water pressures in the basal hydrological system (Mair and others, 2001). The hydrological system was evolving from an inefficient (distributed) to an efficient (channelized) system at that time.

At Finsterwalderbreen, horizontal ice surface velocities were measured up to three times a year between 1994 and 1997 using theodolite surveying of up to 20 stakes drilled into the ice (Fig. 1; Nuttall, 2000). Summer and winter 


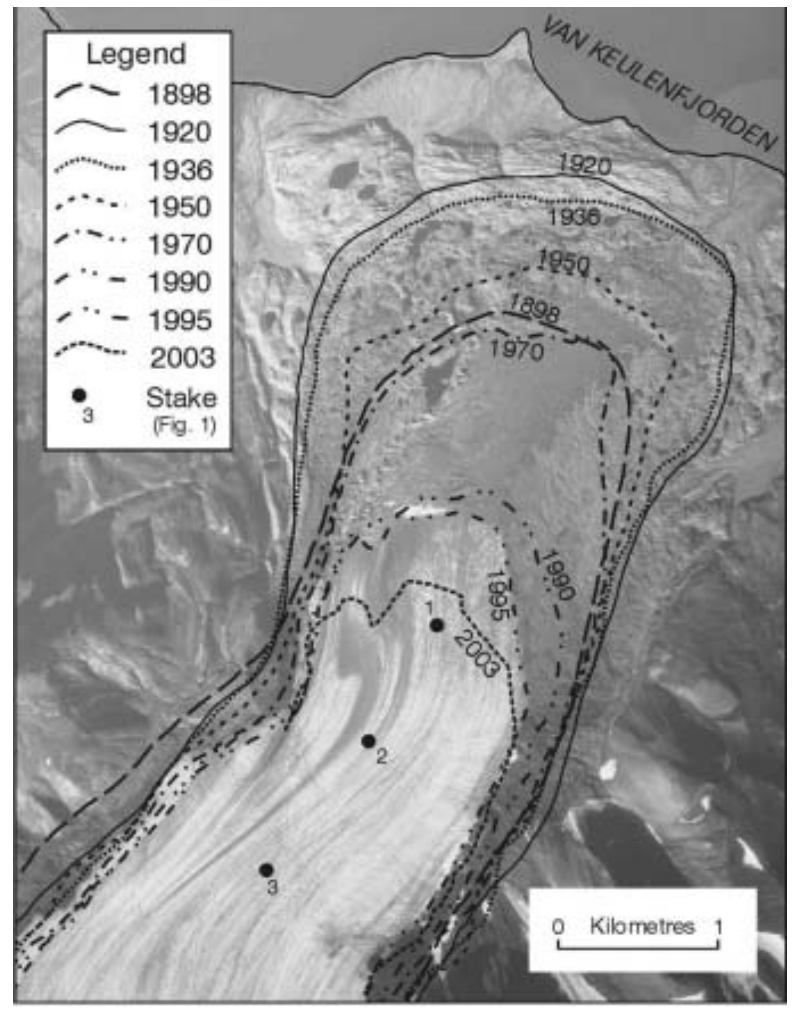

Fig. 2. Glacier terminus positions for 1898, 1920, 1936, 1950, 1970, 1990, 1995 and 2003 derived from topographic maps (18981990), aerial photographs (1995) and LIDAR (light detection and ranging) data (2003). Backdrop is the photograph from 1995 (C) Norsk Polarinstitutt, photograph S95 1113), and stake locations are shown (Fig. 1). Note the remnants of the looped medial moraines, which can be seen near the glacier snout.

velocities showed substantial differences, with overwinter velocities (August-April) typically $10-60 \%$ of springsummer velocities (measured from April to August) (Nuttall and others, 1997).

Velocities measured over periods of 1-3 weeks during August 1994 and 1995 were consistently higher than those measured from April to August (Fig. 4), although errors inevitably become more significant over these shorter measurement periods. These marked seasonal velocity variations imply that basal sliding and possibly subglacial deformation are important components of the total surface velocity.

Mean annual velocities from spring to spring were calculated for up to 3 years where data coverage permitted (Fig. 5). These show broad similarity for the first 2 years (1994/95 and 1995/96) such that any differences are generally within the error bars, but show an increase for the third year of measurement (1996/97) of up to $75 \%$ at all but one of the eleven stakes where data are available (Fig. 5). Unfortunately, seasonal velocities are not available for 1996/ 97, so it is not clear whether this anomaly is due to enhanced summer velocities or higher overwinter velocities.

Although the stakes had long since melted out, cables drilled to the glacier bed at stakes 2 and 6 in 1994 were relocated and surveyed using the global positioning system in summer 2003. This gives average velocities over a period of 9 years for two locations on the lower glacier. These longterm average velocities are very close to the 1994/95 and 1995/96 velocities (Fig. 5), but data for 1996/97 are not

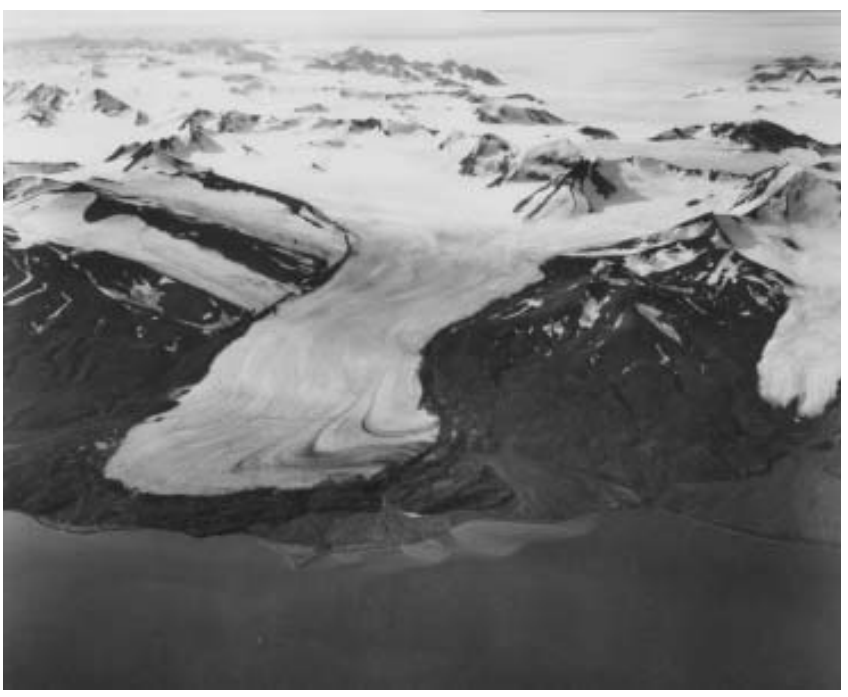

Fig. 3. Oblique aerial photograph of Finsterwalderbreen taken in 1936, looking southwards (C) Norsk Polarinstitutt, photograph S36 3201). Note the looped moraines visible near the terminus and the displaced flowlines higher up the glacier.

available at either of these locations. Mean annual velocities were measured by $\mathrm{O}$. Liestøl at several stakes between summer 1950 and summer 1952 (Nixon and others, 1985). These velocities are similar to the 1994-96 values at stakes 2, 3, 12 and E1, lower at stakes 6 and 8 and similar to the 1996/ 97 values at stakes 10 and 11 (Fig. 5), indicating that year-toyear fluctuations in annual velocities are not confined to the late quiescent phase. It thus seems likely that the higher velocities measured in the upper glacier in 1996/97 are a short-term anomaly. Unlike glaciers in other surge clusters such as Alaska, those in Svalbard seem to undergo a relatively gradual multi-year acceleration from the quiescent to the active phase of a surge, as observed at Fridtjovbreen, $\sim 50 \mathrm{~km}$ to the north of Finsterwalderbreen (Murray and others, 2003). The observed fluctuations at Finsterwalderbreen do not appear to be related to pre-surge acceleration, although this cannot be ruled out based on the existing data.

\section{SUBGLACIAL HYDROLOGY OF FINSTERWALDERBREEN}

It is widely recognized that the subglacial hydrological system plays a central role in surge behaviour, and hence that a temperate or polythermal regime is a prerequisite for a glacier to surge. Subglacial water storage and water pressure are known to be important controls on basal sliding rates and thus control the intra-annual variability observed in total surface velocities at polythermal glaciers (e.g. Copland and others, 2003 and references therein).

The mostly warm base of the glacier inferred from radar and borehole data (Ødegård and others, 1997) is consistent with hydrochemical analyses of the proglacial meltwaters, which show extended contact with subglacial material (Wadham and others, 2001) and with suspended-sediment data indicating that a distributed subglacial hydrological system evolves to a channelized system over the ablation season (Hodson and Ferguson, 1999). Modelling of the subglacial channel network from digital elevation models (DEMs) from 1970 and 1990 indicates that the hydrological system is at least partly pressurized (Hagen and others, 2000). 
Stake 2

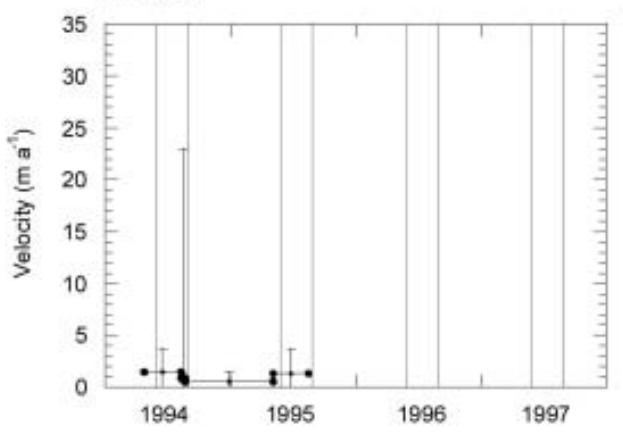

Stake 6

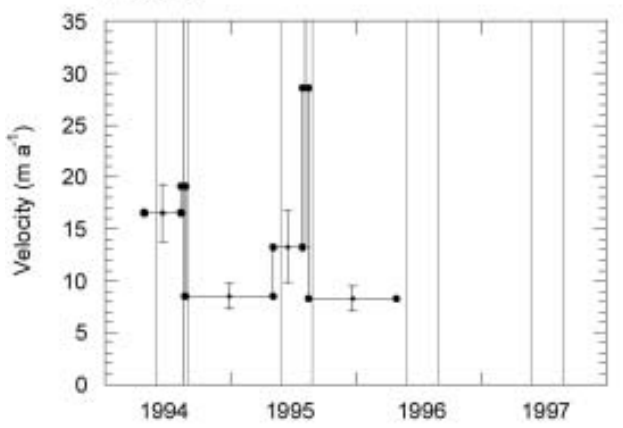

Stake 10

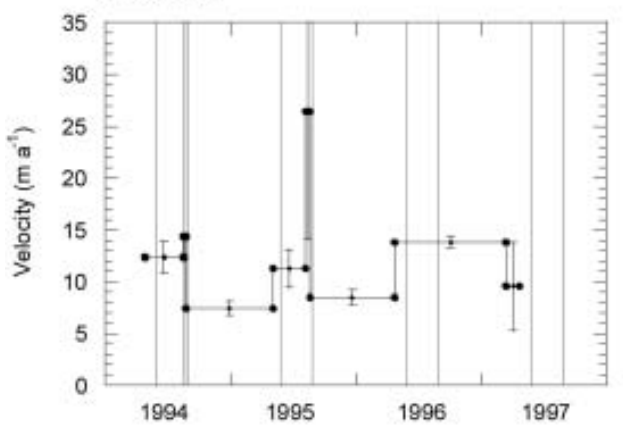

Stake E1

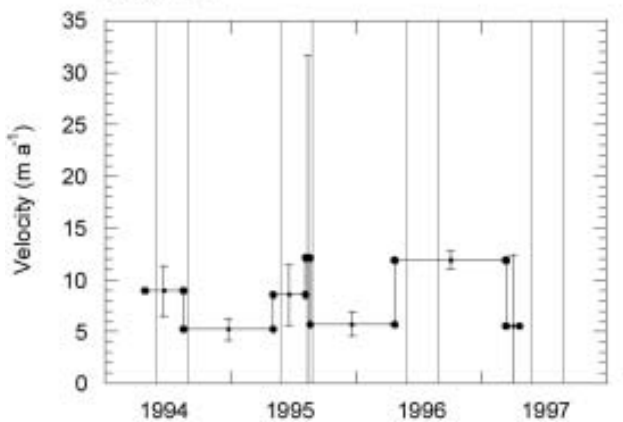

Stake 4

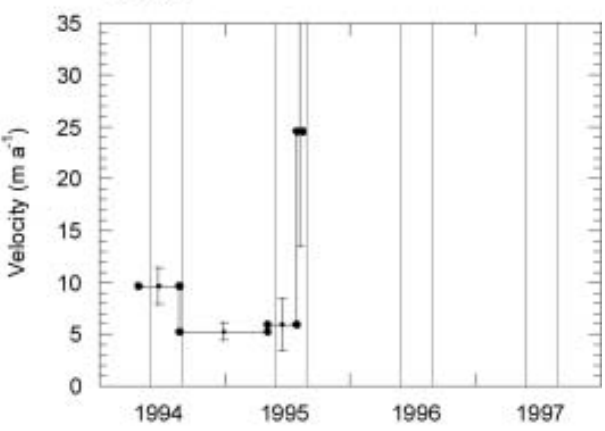

Stake 8

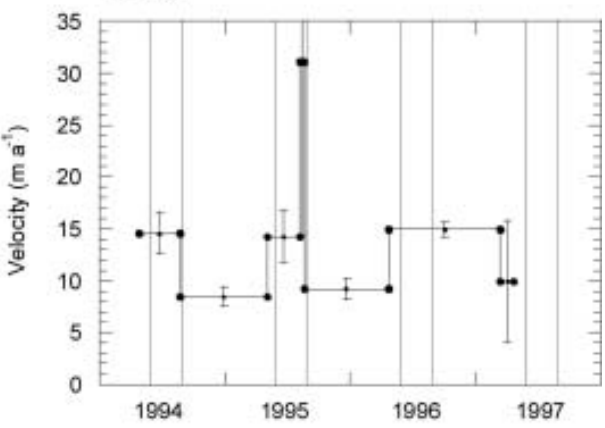

Stake 12

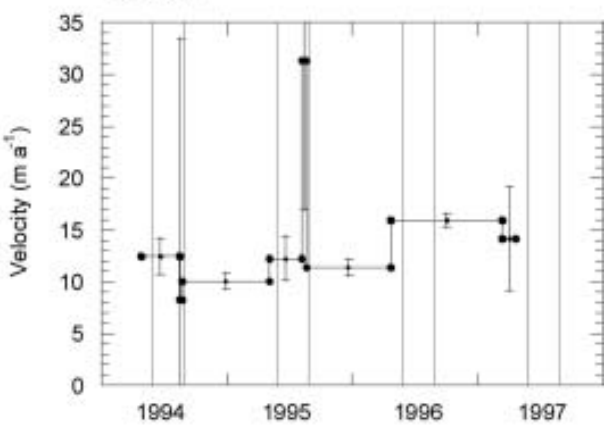

Stake W2

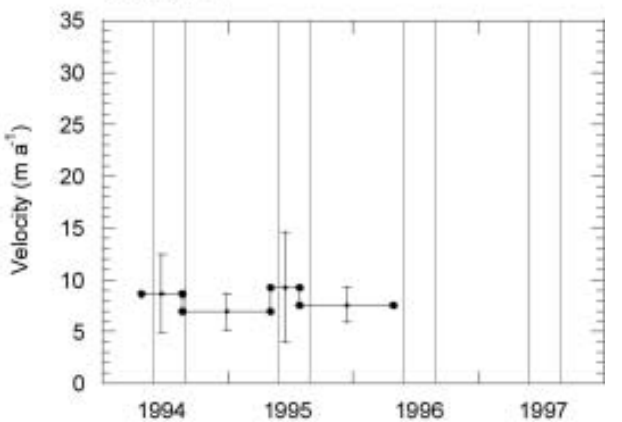

Fig. 4. Time series of measured velocities at selected stakes for the period spring 1994-spring 1997. See Figure 1 for stake locations. Each dot represents a survey date, while horizontal lines indicate mean velocity over each interval. Error bars are plotted centrally on each interval and represent uncertainty in velocity estimates derived as described in the text. Vertical bars enclose the summer months June-August each year. Vertical scale is the same for each graph.

Overwinter subglacial water production and/or storage at Finsterwalderbreen is inferred from the presence of extensive naled ice in the proglacial plain each winter. Chemical analyses of the naled ice indicate extensive contact with subglacial debris and hence subglacial routing (Wadham and others, 2000). The nearby glaciers Penckbreen, Antoniabreen and Kvitskarvbreen have been observed to produce outbursts during the spring, long before air temperatures rise 


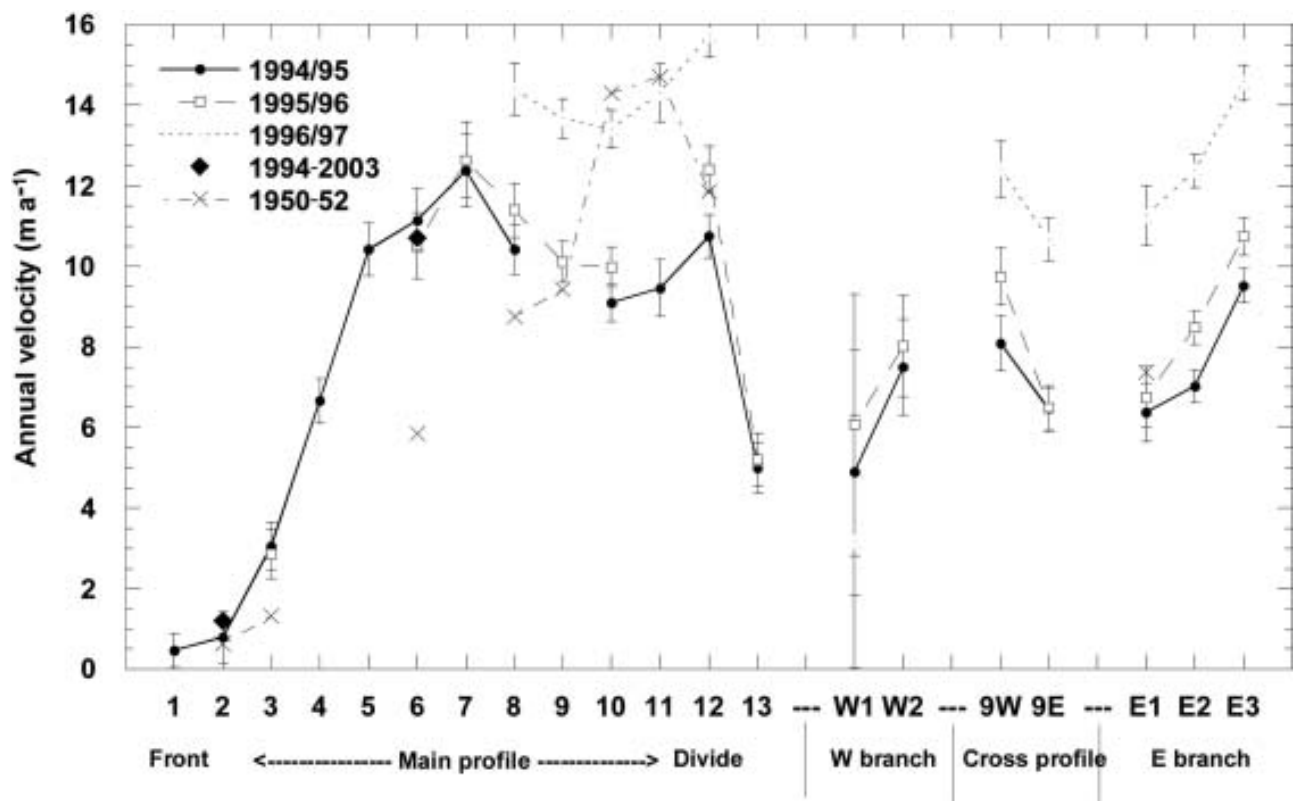

Fig. 5. Annual velocity measurements at stake locations shown in Figure 1 for three consecutive years. Stakes 1-13 are located along an approximate flowline from the head of the glacier to the terminus, while stakes $\mathrm{W} 1$ and $\mathrm{W} 2$ are on the western tributary, 9E and 9W form a cross-profile either side of stake 9, and E1-E3 are located on the eastern side of the main accumulation basin. Also shown are data collected by Liestøl in 1950-52 (Nixon and others, 1985) from repeat stake surveys (crosses), and long-term average values for 1994-2003 from repeat surveying of two cables drilled into the ice (diamonds).

above zero (Nuttall, 2000). It has been suggested that overwinter water storage and migration may be important in surge behaviour (e.g. Lingle and Fatland, 2003).

\section{SOURCES OF SUBGLACIAL WATER}

Air temperatures were measured on the glacier between October 1994 and April 1996, and from these a seasonspecific transfer function was calculated by Høivik (1999) relative to the long-term dataset collected at Longyearbyen airport, $80 \mathrm{~km}$ to the north. Using this long-term dataset, the number of positive degree-days (PDDs) for Finsterwalderbreen was estimated for 1994-96 (Table 1) (Høivik, 1999).

The data indicate that summer 1995 was much warmer than either 1994 or 1996, but this did not produce a higher mean annual velocity (Table 1 ). In Longyearbyen, there was about three times as much rainfall in summer 1994 as in 1995, which explains the greater surface melting seen in 1994 (summer balance was $-1.31 \mathrm{~m}$ w.e. compared to -1.06 mw.e. in 1994) despite the lower air temperatures (Table 1). This meltwater, plus the rainwater itself, led to a much higher proglacial discharge for the ablation season in 1994 (Table 1), and is likely to have increased the volume of water in the subglacial hydrological system. Despite this, the mean annual velocities for 1994 and 1995 are not significantly different (Table 1; Fig. 5). However, the following year (1996) showed intermediate values for both summer air temperatures and rainfall, but a significantly higher annual velocity than the previous 2 years (Table 1 ). We suggest that this is most easily explained by a change in subglacial water storage. All stakes for which 1997 annual velocities are available are located up-glacier of the riegel, since the lower stakes had melted out by then (Fig. 1).

\section{BALANCE VELOCITIES}

The width-averaged mean annual velocity at the crosssection of the glacier at stakes 9E, 9 and 9W (Fig. 1) was calculated to be $8.4 \mathrm{~m} \mathrm{a}^{-1}$ for the period 1994-97 (Nuttall, 2000). A balance velocity of $10.2 \mathrm{~m} \mathrm{a}^{-1}$ for this $0.45 \mathrm{~km}^{2}$ cross-section was calculated using long-term mass-balance measurements from 1950 onwards (Nuttall and others, 1997). Since the measured velocity is about $80 \%$ of the balance velocity, this implies a build-up of $\sim 5 \mathrm{~cm} \mathrm{a}^{-1}$ on average over the $15 \mathrm{~km}^{2}$ area up-glacier of the cross-section. This is consistent with the observed trend for thickening of the glacier in this area between 1970 and 1990 calculated from DEM subtraction (Nuttall and others, 1997), although errors are difficult to quantify on these values. Before the higher 1996/97 annual velocities were acquired, balance velocity calculations showed that the glacier was flowing at

Table 1. Hydrological factors likely to contribute to basal sliding velocities at Finsterwalderbreen. Summer balance calculated from stake measurements are given in metres water equivalent ( $m$ w.e.). Rainfall data are given for Longyearbyen airport for June-August each year (JJA), from the Statistics Norway website (www.ssb.no). The mean JJA rainfall for 1988-98 was $51 \mathrm{~mm}$

\begin{tabular}{cccccc}
\hline Year & $\begin{array}{c}\text { Summer } \\
\text { balance } \\
\text { (Nuttall, } \\
\text { 2000) } \\
\text { mw.e. }\end{array}$ & $\begin{array}{c}\text { Proglacial } \\
\text { discharge } \\
\text { (Hodson and } \\
\text { others, 1997) } \\
10^{6} \mathrm{~m}^{3} \mathrm{a}^{-1}\end{array}$ & $\begin{array}{c}\text { PDDs } \\
\text { (Høivik, } \\
1999)\end{array}$ & $\begin{array}{c}\text { JJA rainfall } \\
\text { (www.ssb.no) }\end{array}$ & $\begin{array}{c}\text { Stake 8 } \\
\text { annual } \\
\text { velocity } \\
\text { (Fig. 5) }\end{array}$ \\
& & & $\mathrm{mm}$ & $\mathrm{m} \mathrm{a}^{-1}$ \\
\hline 1994 & $-1.31 \pm 0.2$ & 57 & 85 & 89 & $10.4 \pm 0.6$ \\
1995 & $-1.06 \pm 0.2$ & 24 & 110 & 28 & $11.4 \pm 0.7$ \\
1996 & n.d. & n.d. & 99 & 58 & $14.4 \pm 0.6$
\end{tabular}


only $60 \%$ of the balance velocity (Nuttall and others, 1997), thus emphasizing the need for long-term average velocities for this type of comparison.

\section{CONCLUSIONS}

Finsterwalderbreen, unlike some other Svalbard glaciers, retains the thermal regime necessary to permit the high basal sliding velocities characteristic of the active phase of a surge. Hydrological and hydrochemical observations, modelling studies and seasonal velocity variations indicate that the subglacial hydrological system is both active and variable. Mean annual velocity variations of up to $75 \%$ in successive years imply substantial short-term changes in the subglacial hydrological system, as these changes cannot easily be explained by differences in air temperatures or rainfall rates. This active and highly variable subglacial hydrological system is likely to be linked to the surge behaviour of this glacier. Ongoing monitoring indicates that the glacier continues to evolve in a way consistent with the quiescent phase of a surge cycle, although the retreat of the terminus, well behind the 1898 limit, might also indicate that the quiescent phase has lengthened due to unfavourable mass-balance conditions.

\section{ACKNOWLEDGEMENTS}

The authors are grateful to J.O. Hagen, A. Fox, J. Wadham, R. Ødegård, A. Jackson, A. Fox and M. Sund for assistance with fieldwork, and the Norsk Polarinstitutt for air photographs. Fieldwork was supported by the European Union Environment programme (grant ENV4-CT97-0490). We also thank two anonymous referees for constructive comments that have improved the paper.

\section{REFERENCES}

Copland, L., M.J. Sharp and P.W. Nienow. 2003. Links between short-term velocity variations and the subglacial hydrology of a predominantly cold polythermal glacier. J. Glaciol., 49(166), 337-348.

Dowdeswell, J.A., G.S. Hamilton and J.O. Hagen. 1991. The duration of the active phase on surge-type glaciers: contrasts between Svalbard and other regions. J. Glaciol., 37(127), 388-400.

Dowdeswell, J.A., R. Hodgkins, A.M. Nuttall, J.O. Hagen and G.S. Hamilton. 1995. Mass balance change as a control on the frequency and occurrence of glacier surges in Svalbard, Norwegian High Arctic. Geophys. Res. Lett., 22(21), 29092912.

Eisen, O., W.D. Harrison and C.F. Raymond. 2001. The surges of Variegated Glacier, Alaska, U.S.A., and their connection to climate and mass balance. J. Glaciol., 47(158), 351-358.

Etzelmüller, B., G. Vatne, R.S. Ødegård and J.L. Sollid. 1993. Dynamics of two subpolar valley glaciers: Erikbreen and Hannabreen, Liefdefjorden, northern Spitsbergen. Geogr. Ann., 75A $\mathbf{A}(1-2), 41-54$.

Hagen, J.O., O. Liestøl, E. Roland and T. Jørgensen. 1993. Glacier atlas of Svalbard and Jan Mayen. Norsk Polarinst. Medd. 129.
Hagen, J.O., B. Etzelmüller and A.-M. Nuttall. 2000. Runoff and drainage pattern derived from digital elevation models, Finsterwalderbreen, Svalbard. Ann. Glaciol., 31, 147-152.

Hamberg, A. 1905. Astronomische, photogrammetrische und erdmagnetische Arbeiten der von A.G. Nathorst geleiteten schwedischen Polarexpedition 1898. Kungliga Svenska Vetenskapsakademien Handlingar, 39(6), 1-62.

Hamilton, G.S. and J.A. Dowdeswell. 1996. Controls on glacier surging in Svalbard. J. Glaciol., 42(140), 157-168.

Hart, J.K. and R. Watts. 1997. A comparison of the styles of deformation associated with two recent push moraines, south Van Keulenfjorden, Svalbard. Earth Surf. Proc. Land., 22(12), 1089-1107.

Hodgkins, R., J.O. Hagen and S.E. Hamran. 1999. 20th century mass balance and thermal regime change at Scott Turnerbreen, Svalbard. Ann. Glaciol., 28, 216-220.

Hodson, A.J. and R.I. Ferguson. 1999. Fluvial suspended sediment transport from cold and warm-based glaciers in Svalbard. Earth Surf. Proc. Land., 24(13), 957-974.

Hodson, A.J., M. Tranter, J.A. Dowdeswell, A.M. Gurnell and J.O. Hagen. 1997. Glacier thermal regime and suspendedsediment yield: a comparison of two high-Arctic glaciers. Ann. Glaciol., 24, 32-37.

Høivik, L.P. 1999. Temperaturregimet til en liten surgebre i hvilefasen; Hessbreen, Svalbard. (MSc thesis, University of Oslo.)

Jiskoot, H., P. Boyle and T. Murray. 1998. The incidence of glacier surging in Svalbard: evidence from multivariate statistics. Comput. Geosci., 24(4), 387-399.

Lefauconnier, B. and J.O. Hagen. 1991. Surging and calving glaciers in eastern Svalbard. Norsk Polarinst. Medd. 116.

Liestøl, O. 1969. Glacier surges in West Spitsbergen. Can. J. Earth Sci., 6(4), 895-897.

Lingle, C.S. and D.R. Fatland. 2003. Does englacial water storage drive temperate glacier surges? Ann. Glaciol., 36, 14-20.

Mair, D., P. Nienow, I. Willis and M. Sharp. 2001. Spatial patterns of glacier motion during a high-velocity event: Haut Glacier d'Arolla, Switzerland. J. Glaciol., 47(156), 9-20.

Murray, T., A. Luckman, T. Strozzi and A.M. Nuttall. 2003. The initiation of glacier surging at Fridtjovbreen, Svalbard. Ann. Glaciol., 36, 110-116.

Nixon, W.A. and 6 others. 1985. Applications and limitations of finite element modeling to glaciers: a case study. J. Geophys. Res., 90(B13), 11,303-11,311.

Nuttall, A.-M. 2000. The quiescent phase of Finsterwalderbreen, a surge type glacier in Svalbard. (PhD dissertation, University of Bristol.)

Nuttall, A.-M., J.O. Hagen and J. Dowdeswell. 1997. Quiescentphase changes in velocity and geometry of Finsterwalderbreen, a surge-type glacier in Svalbard. Ann. Glaciol., 24, 249-254.

Ødegård, R.S., J.O. Hagen and S.E. Hamran. 1997. Comparison of radio-echo sounding $(30-1000 \mathrm{MHz})$ and high-resolution borehole-temperature measurements at Finsterwalderbreen, southern Spitsbergen, Svalbard. Ann. Glaciol., 24, 262-267.

Raymond, C.F. and W.D. Harrison. 1988. Evolution of Variegated Glacier, Alaska, U.S.A., prior to its surge. J. Glaciol., 34(117), 154-169.

Wadham, J.L., M. Tranter and J.A. Dowdeswell. 2000. The hydrochemistry of meltwaters draining a polythermal-based high Arctic glacier, southern Svalbard. II. Winter and early spring. Hydrol. Process., 14(10), 1767-1786.

Wadham, J.L., R. Hodgkins, R.J. Cooper and M. Tranter. 2001. Evidence for seasonal subglacial outburst events at a polythermal glacier, Finsterwalderbreen, Svalbard. Hydrol. Process., 15, 2259-2280. 